\title{
特集 難治性肛門疾患
}

\section{IV-1 難治性裂肛の治療}

\section{一一用手肛門搪張法の有用性について—}

\author{
札幌いしやま病院 \\ 石山勇, 司 \\ 札璂医科大学第 1 外科 \\ 佐々 木一晃
}

\begin{abstract}
裂肛も慢性の結過をとると難治性となり外科治療の対象となる，裂肛の手汸法としては，用手肛門㹡張 法, 凍結療法, 種々の内括約觔切断法, 裂肛切除・皮膚弁移動法などが行なわれている.これらのうちで用 手肛門拡張法は，再発や術後の肛門機能不全等から術式として否定的な意見も存在する.しかし，われわれ は，裂肛に対して原則として用手肛門搪張法を最近の10年問で 3,142 例に行ってきた.これらのうち817例は， 肛門狭䆣をきたして難治性となり，肥大乳頭（anal polyp），見張り疮（skin tag）を認める症例である，さ らには瘦孔を形成しているような症例に対しても，本法を原則として入院することなく施行しており良好な 結果を得ている。 これらの症例の約 $5 \%$ に再発を認めるが，再度外来にて用手肛門拢張法を施行している. 本法は注意媣く行うことにより， soiling，incontinence をきたす症例もなく，非常に有用な手技である。
\end{abstract}

索引用語：難治性裂肛, 裂肛手術術式, 用手肛門搪張法,

はじめに

裂肛とは肚門上皮の裂創あるいは潰瘍の総称で，その 発生機序に上り狭窄型, 脱出型, ぜい弱型, 症候型に分 類される11。このうち一般に裂肛といらと狭窄型を意味 し，它の成因汁不明な点も多いが，急性裂㓣の反復上， 裂創部分浽感染学繰り返し，その周辺の内括約筋に炎症 による瀻維化を生じ曒痕性狭窄をきたす，また，裂創周 辺の上皮にむ慢性炎症が生じ肥大乳頭 (anal polyp), 見 張り㾌 (skin tag) 随伴し，肛門狭窄とともに裂肛三 徵を呈する．時には，感染により瘦孔が形成されること む古る。このよらに慢性化し，肛門狭窄を来した症例で は，何らかの外科的処置が必要となる. 外科的処置とし ては，種々の内括約管切断法，裂創切除・皮膚弁移動法 （SSG）が一般的に広く行われているが，難治性㹨窄型 裂肛症例に用手肛阿㹡張法のみで治療している報告はな い.われわれ開院当初より原則としてすべての狭窄型 裂肛に本法を施行し，良好な呫果を得ているのでここに 報告する.

\section{I. 対象および方法}

札沅いしやま病院代おいて1981年1月加ら1990年12月 までの10年間仁治療した肚門疾患症例の総数注 55,293 例 であり，このうち裂肛症例杖6，157例（11.1\%）である。 軽度の裂肛症例は保存的治療にて完治するが, 裂肛症例 051.0\%，3,142例に対して外科的沿療，当院にては用 手肛門应張術が行われた. 本法は20 40歳台の症例に多 く行われている(表1). Skin tag, anal polyp の切除 が同時に行われた症例は817例である.

手技：ジャック・ナイフ体位（図1）とし，麻醉は仙 骨裂孔からの硬膜外麻醉で行っている2). 使用薬郕は, $2 \%$ キロカイン $10-12 \mathrm{ml}$ を用い，仙骨裂孔への穿刺は $98.2 \% 22$ とほぼ全例で可能である.

十分な筋驰緩が得られてから，用手搪張法を図 2 のご とく施行する.この時には，狭窄の程度に注意しながら， まず一示指を入れ，ついで两示指を入れる. 翰状の硬結 を感知しながら，片方の中指も入れ，これを固定して反 対側の示指で搪張する，拉張を行ら時の注意点壮，指先 で硬結を良く感知しながら行うことが大切で，絶対むや みに搪張してはならない，昖張の程度は，一般に左右の 


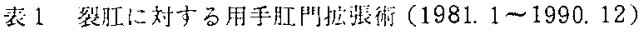

新患総数 55,293 (うち裂肚患者 6,157)

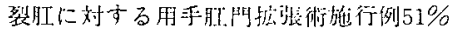

\begin{tabular}{|c|c|c|c|c|c|c|c|c|c|c|}
\hline 年路 & $0 \sim$ & $10 \sim$ & $20 \sim$ & $30 \sim$ & $40 \sim$ & $50 \sim$ & $60 \sim$ & $70 \sim$ & $80 \sim$ & 合計 \\
\hline 0 & $\begin{array}{c}0 \\
(0)\end{array}$ & $\left(\begin{array}{c}44 \\
5\end{array}\right)$ & $\begin{array}{c}238 \\
(15)\end{array}$ & $\begin{array}{c}505 \\
(78)\end{array}$ & $\begin{array}{c}294 \\
(54)\end{array}$ & $\begin{array}{c}226 \\
(34)\end{array}$ & $\begin{array}{l}82 \\
(15)\end{array}$ & $\left(\begin{array}{c}26 \\
(3)\end{array}\right.$ & $\begin{array}{c}0 \\
(0)\end{array}$ & $\left(\begin{array}{r}1,415 \\
204\end{array}\right)$ \\
\hline 우 & $\begin{array}{c}0 \\
(0)\end{array}$ & $\begin{array}{c}78 \\
(39)\end{array}$ & $\begin{array}{c}520 \\
(189)\end{array}$ & $\begin{array}{c}491 \\
(189)\end{array}$ & $\begin{array}{c}347 \\
(118)\end{array}$ & $\begin{array}{c}218 \\
(55)\end{array}$ & $\begin{array}{l}60 \\
(20)\end{array}$ & $\begin{array}{c}10 \\
(3)\end{array}$ & $\begin{array}{c}3 \\
(0)\end{array}$ & $\begin{array}{r}1,727 \\
(\quad 613)\end{array}$ \\
\hline 計 & $\begin{array}{c}0 \\
(0)\end{array}$ & $\left(\begin{array}{c}122 \\
44)\end{array}\right.$ & $\begin{array}{c}758 \\
(204)\end{array}$ & $\begin{array}{c}996 \\
(267)\end{array}$ & $\begin{array}{c}641 \\
(172)\end{array}$ & $\begin{array}{c}444 \\
(89)\end{array}$ & $\begin{array}{c}142 \\
(35)\end{array}$ & $\begin{array}{c}36 \\
(6)\end{array}$ & $\begin{array}{c}3 \\
(0)\end{array}$ & $\begin{array}{c}3,142 \\
\left(\begin{array}{r}817\end{array}\right)\end{array}$ \\
\hline
\end{tabular}

（）内は, skin tag 切除, anal polyp 切除付加した症例.

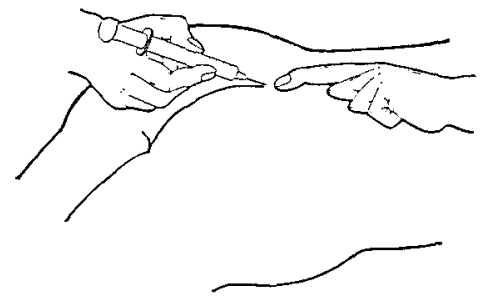

図 1 手術時の体位と麻醉（仙骨硬膜外麻酷）
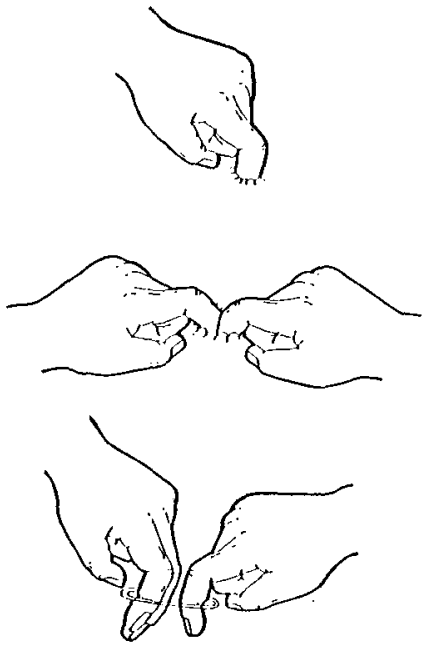

図 2 用手肚阴拉張法の手技

指先が $1 〜 2 \mathrm{~cm}$ 開く位を目安とする.

ついで, anal polyp, skin tag 熟めるなら切除する (図 3). skin tag 沏除して開放創とし，anal polyp は絹糸または McGiveney で結禁する.瘦孔が存在する ならこれも開放するが，SSG では漬痬部分の切除が行 われる（図 4）のに対して，われわれの手技では潰瘍部 分には手を加えない，㜢孔が梁かったり，大きな skin tag を伴っている症例では，1〜2月間入院することむ あるが，それ以外は原則として外来治療としている。
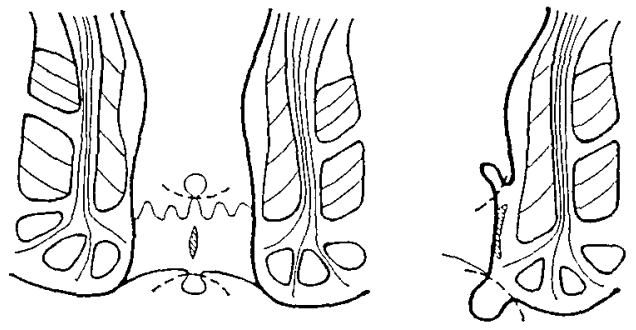

図 3 用手肛閏拡張術時 skin tag, anal polyp の切除範困

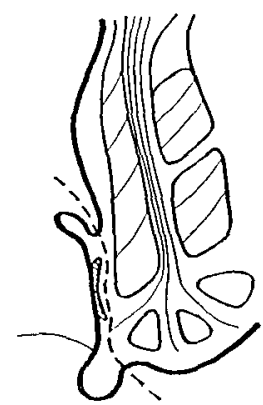

図 4 SSG の切除箸囲

\section{II. 結 果}

最近の10年間に裂肛症例の51.1\%に用手肛門㹡張法を 施行した。一般に，用手肛門抬張法のみの時は，翌日 の排便から痛みは著しく減少する. skin tag, anal polyp も切除した症例では，ピリピリした痛みなどは存在 するが，排便後に持続する疼痛は消失する。一般に，裂 創部分は10〜14日間で肛門上皮によって被われる。

症例を提示与る（図 5，6).

1988年に用手肛門㹡張法を施行した症例において，そ の後の経過をアンケート調査した（表2). アンケート 調查の回收率は $84 \% ， 84$ 例であった。このうち経過良好 は，74例 (88.1\%) と大部分を占めた．10例（11.9\%） の経過になんらかの不満がみられている，切れないが何 

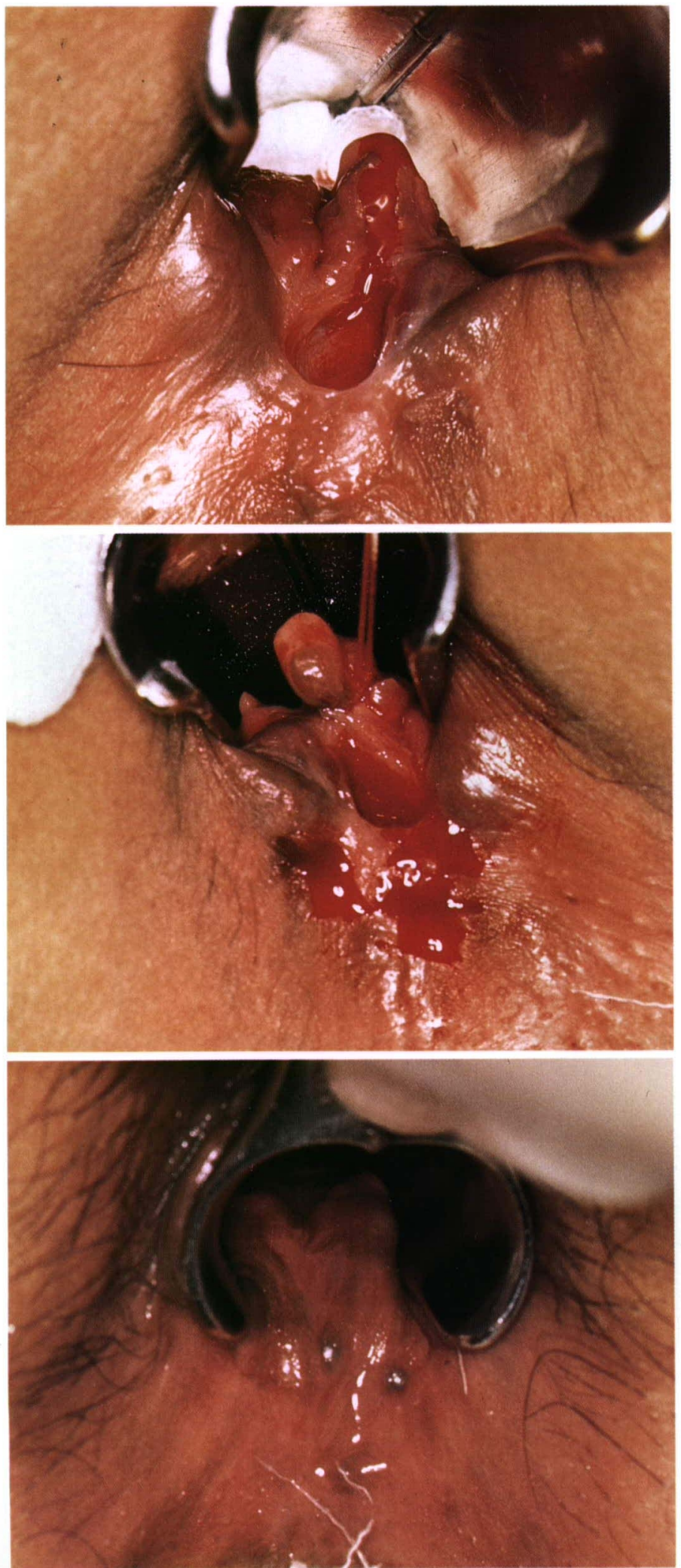

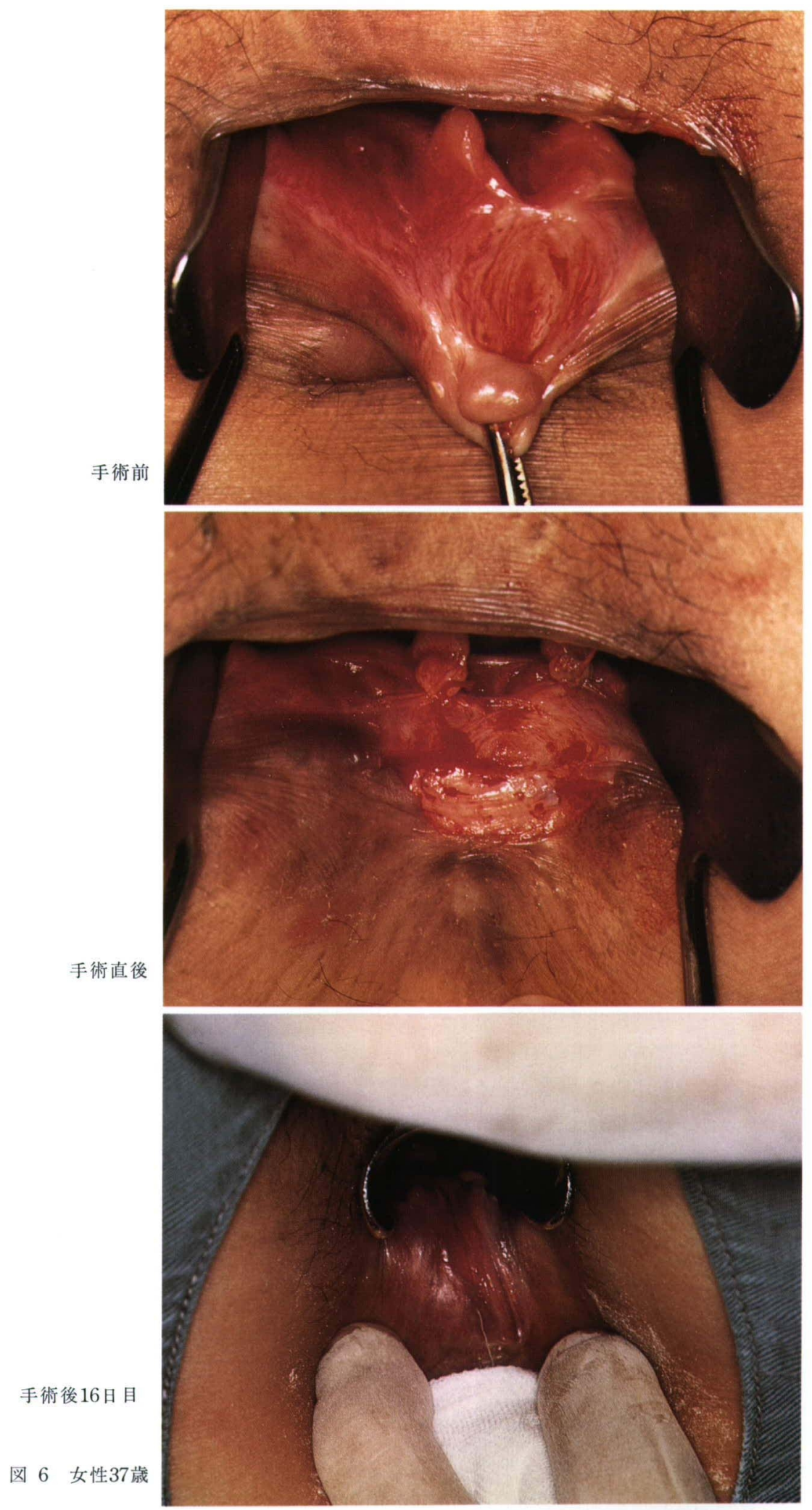
表 2 術後の経過

\begin{tabular}{|c|c|}
\hline \multicolumn{2}{|c|}{$\begin{array}{l}\text { 一用手肘间搪張後 } 1 \text { 年経過した } 84 \text { 例一 } \\
\text { (平成元年 } 1 \text { 月〜 } 12 \text { 月・回収率 } 84 \% \text { ) }\end{array}$} \\
\hline 良 好 & 74 例 $(88.1 \%)$ \\
\hline 切れないが何らかの症状がある & 6 例 $(7.1 \%)$ \\
\hline \multirow[t]{2}{*}{ ときどき切れる } & 4 例 $(4.8 \%)$ \\
\hline & 84 例 $(100.0 \%)$ \\
\hline \multicolumn{2}{|c|}{ 何らかの症状があるもの6 例の内訳 } \\
\hline 脱出する & 5 例 \\
\hline 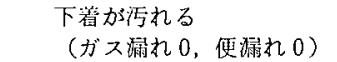 & 1例 \\
\hline
\end{tabular}

らかの症状があるとの6例についてみると，そのうちの 5 例は内侍核に付随した裂肛であり，肚門狭窄が解消さ れたことにより内痔核の脱出が症状として，前面に出た むのである，あとの1例は，下着が污れるという訴えで あるが，これも内庤核脱出によるものであり， soiling や肛門括約筋不全は認めていない，4例 (4.8\%) にと きどき切れるとの症状を認めた。これは肛門抬張不足ま たは再発によるものと考えられ，再度の用手肛門抬張法 を施行した。

\section{III. 考察}

裂肛に対する用手肛門拡張法は，古くから裂肛に対し て行われてきた：しかし，搪張が不十分であると再発の 頻度が高く，抬張し過ぎると肚門機能不全の症状を訴え ることがある゙2。そそのた，最近では種々の肍門括約筋 切開術や SSG などが主流となり多くの報告4-7がある. しかし，われわれは，裂肛の三徴を備えた難治性裂肛に 対しても，原則として用手肛門抾張法を外来で施行して おり良好な結果を得ている，そこで，われわれの常用し ている用手肛門拚張法の利点を他の手技と比較しつつ考 察する。

後方内括約筋切断術8) ${ }^{8}$ ，手術後の開放創が大きく， 治瘉までの期間が長い，このために，この部分を皮膚で 被うCammel の方法"'が発展し SSG 法として汎用され ている。この方法は裂創の治療に関しては非常に有用で 亦るが，奥に滑らせた皮膚と粘膜の間に横に走る曒痕が 生じ，これが術後の不快感，伸展不良の原因となること がある゙．これは，潰瘍部分を切除して皮膚と粘膜を縫 合することにも問題があると考える. Whitehead 肛門 で明らかなように肛門移行上皮を久除させた皮膚と粘膜 の縫合は，岩垂(10)がいううに縫合部口側の粘膜の旮 血, 出血等の不都合を生じる.これに対して，Parksの 報告 ${ }^{11)}$ 以来広く行和れている側方内括約筋切断術 (LS. IS）は，再発のみならず minor incontinence の発生
率も低く，最近では裂肚の外科的治療として最も推奖さ れている.

われわれは, LSIS に minor incontinence の発生が 少ない理由の一つに，潰瘍部分を切除しないことが大切 な要因と考えている．著者らが常用している用手肛門㹡 張法も skin tag, anal polyp は切除しても, LSIS 上 同様に潰瘍部分は切除しない，一般に，潰瘍はその原因 が除去されたならば自然に治瘠すると考える．われわれ の経験では，用手肛門㹡張後 skin tag，anal polyp を 切除した創と潰瘍部分と比較すると，溃瘍部分の治り方 がはるかに早いように考えている。

Watts $ら^{3)}$ は用手肛門搪張法施行後排便障害が $25 \%$ に みられたと報告して以来，その後の裂肍の手術としては SSG，LSIS が主流となり，用手肛門拉張法の報告は少 ない，しかし，大谷ら"(4根治性の点では不十分である が，外科医としてぜひ習得したい手技の一つであると報 告している.

最近, Giebel ら ${ }^{12)}$ は用手肛門搪張法と LSIS を比較 検討した。これによると，有效性は雨者ほぼ同程度で， 再発率は用手肛門㹡涱法で $19.7 \%$ L LSIS 上り約 5\% 高率であった。しかし，incontinence は逆に用手肛門桩 張法で $1.3 \%$ と LSIS より約 $5 \%$ 低く，操作の簡便性か ら用手拉張法江裂肛の first choice の治療法として考 慮すべきであると報告している，Giebel ら ${ }^{12}$ は全身麻 酔下に本法を行っているが，用手肛閒拡張法施行時の重 要な点は十分な肚門括約筋の筋驰緩を得ることで，これ が不十分であるならその効果に不都合を生じるといって も過言でない，つまり，十分な笳弛緩状態では微妙な内 括約筋の輪状の狭窄を良く触知でき，その輪状の硬結の みを注意深く，愛護的注应張するという感じを誰しも持 つことが可能であると確信する，今までの著者らは，外 来で用手抬張法を施行するために，すでに報告2)したよ うに仙骨硬膜外麻酔を常用している，過去の報告3での 用手肛門拡張法の成績の悪さ，すなわち，㹡張不十分に よる再発，拉張し過ぎによる内括約筇の不可逆的な損傷 などは，すべて筋驰緩の不十分な条件下でのむやみな拉 張が原因と考えている。

肛門機能不全という合併症は，内括約筋の切開，ある い注抎張に伴うむので，用手拡張法のみならず SSG， LSIS でも発生がみられる10,12)。これを予防するために は，狭窄の程度，そして本来の肛門の広さを予測し，搪 張操作を必要最小限にとどめるべきである，われわれの 行っている用手肛門抾張法は外来で簡単に行える. 再発 例に対し再度の应張法は效果がないとも報告13)されてい るが，再発したなら，末た用手搪張を施行する位の考え 方で行らことが不可逆的な損傷を予防するために重要で 
あろら。

$$
\text { まとめ }
$$

難治性裂肛を含め, われわれの行っている用手肛門搪 張の有用性, 注意点を報告した.

\section{文献}

1）高野正博，長尾利治，藤好健共：裂肛の発生機 序と病態. 日本大腸肛門病会誌 $30: 401-404$, 1977

2）佐々木一晃, 石山勇司, 中山䅱ほ加：肛門部 手術化打ける仙骨硬膜外麻醚一自験例 11，736 例の険討を中心に一。臨外 40:1405-1407， 1985

3) Watts JM, Benntt RC, Geligher JC: Streching of anal sphincter in treatment of fissure in ano. Br Med J 2:342-343, 1964

4) 大谷忠久, 柳田謙蔵, 永澤康滋注か：裂肛の重 症度と治療. 消外 13：1389-1395，1990

5）高野正博：裂屸の手術一歯状線形成 SSG法一。 日本大腸肛閏病会誌 $42: 492-497,1989$

6) Hunter A: Anorectal problems: Lateral subcutaneous anal sphincterjtomy. Dis Co- lon Rectum 18:665-668, 1975

7）隅越幸男：裂肛の手術手技. 外科治療 $26: 386-$ 396, 1972

8) Eisenhammer $S$ : The evaluation of the internal anal sphincterotomy operation with special reference to anal fissure. Surg Gynecol Obstet $109: 583-590,1959$

9) Cammel AC: Modern surgical treatment of hemorrhoid and a new rectoplasty. Am J Surg $75: 320-3401948$

10）第106回大腸肛門病懇談会：ビデオテープによ る裂肛の手術手技の検討. 日本大腸肛門病会誌 $40: 472-485,1986$

11) Parks AG: The management of fissure-inano. Hosp Med 1:739, 1967

12) Giebel GD, Horch R: Treatment of anal fissure: A comparison of three different forms of therapy. Arch Jpn Chir 58:126133, 1989

13) Goliger JC: An evaluation of internal sphincterotomy and simple sphincter-stretching in the treatment fissure-in-ano. Surg Clin North Am $45:$ 1299-1304, 1965

\title{
The Treatment of Severe Anal Fissure by Anal Stretch
}

\author{
Y. Ishiyama \\ Sapporo Ishiyama Hospital, Sapporo, Hokkaido \\ K. Sasaki \\ First Department Surgery Sapporo Medical College, Sapporo, Hokkaido
}

The methods of surgical treatment for anal fissure are anal stretch, subcutaneous sphincterotomy, sliding skin gcaft, etc. Some investigators reporeed that anal stretch was not a useful technique for anal for anal fissure. But 3,142 cases of anal fissure were treated by anal stretch in our outpatients clinic. In 817 cases of these patients, severe anal fissure with anal polyp and skin tag were treated by the same method. And some cases with anal fistel were operated on by the laying open method and anal stretch in outpatients clinic, too.

In cases of relapse we recommend anal stretch again. We propose anal streech gently performed under caudal anesehesia. And in our follow up study, we didn't find any patient complaining about soiling and incontinence. 